\title{
The Role of the Public Policy Network in Making and Implementing Anti-Corruption Policies in Palestine
}

\author{
Ismail Iriqat $^{1} \&$ Khaireyay Radwhan Yehya $^{2}$ \\ ${ }^{1}$ Assistant professor, Birzeit University, Palestine \\ ${ }^{2}$ Assistant professor, Al-Istiqlal University, Jericho, Palestine \\ Correspondence: Ismail Iriqat, Assistant professor, Birzeit University, Palestine
}

Received: January 7, 2020 Accepted: March 9, 2020 Online Published: April 9, 2020

doi:10.5539/res.v12n2p1

URL: https://doi.org/10.5539/res.v12n2p1

\begin{abstract}
As a result for the official and unofficial interactions between many effective sides on both local and central levels, and as a result for the well of the policies network within its different parts such as the legislative council, civil society organizations, financial and administrative audit office, authors, parities and citizens as well as foreign parts such as the international bank and some donating countries, the polices networks started to develop itself and started to work in cooperation with other parties. The networks accomplished all stages in the absence of the legislative council from 2008 till 2019. However, the result of its accomplishments started with short term plans from 1998-2010, in the last year the corruption law as announced, the anti-corruption commission was established. Therefore, the three pillars of anti-corruption were completed including prosecution and anti - corruption court as a type of judicial independence. The Anti-Corruption Law and Strategy has become a systematic policy in all Palestinian public sector institutions. In mid-2019, the PAA obtained a license from the Palestinian Ministry of Higher Education to open the Anti-Corruption Academy for Higher Education, which follows the vision and objective of the Anti-Corruption Commission, which is administratively independent, which will grant a Master's degree and a higher diploma to its members. Thus, we can note the integrated role of the Anti-Corruption Policy Network from implementation to evaluation.
\end{abstract}

Keywords: policy network, corruption, forms of corruption, governmental sector, citizens

\section{Introduction}

In the $21^{\text {st }}$ century, the public policy network has emerged, as the state did not remain the only responsible side on designating and implementing public policies. Political parties and stakeholders as well pressure groups in addition to parliaments participated and observed this implementation.

The organizations of the Palestinian national authority were established in 1994, however, this establishment accompanied with administrative corruption in the public sector, it was exposed in the report of the public control commission report as well as the office of administrative and financial control in 1997. In the same time, the report of the international bank of 1998 confirmed the existence of this corruption; and therefore the legislative council called for reforms through public policies network and the issuance of illegal earning law number 1 of 2005, that was activated only in 2010 .

At 2012; in order to strengthen its role in the fight against corruption, the Palestinian Anti-Corruption Authority, in partnership with all its partners in the national integrity system, issued a national strategy to combat corruption (2012-2014), the first national strategy to reduce corruption in Palestinian public institutions. In preparing this strategy, the Commission adopted a participatory approach, involving all segments of society in discussing the strategy.

To demonstrate the role and impact of the policy network in the formulation and implementation of public policies in Palestine, including in particular anti-corruption policies, is sufficient role to effectively reduce the spread of corruption in public Palestinian institutions.

\section{Area Description}

\subsection{Sample of the Study}

The material of this study is represented by the components of the public policy-making network in Palestine (the Anti-Corruption Commission, the Office of Financial and Administrative Supervision, the General Personnel Bureau, the Judiciary, Parties, civil society institutions, the media, the Legislative Council, and the citizen), personal interviews were 
the main tool for collecting data through Interviewing: Chairman of the Anti-Corruption Commission, Legal Adviser to the Anti-Corruption Authority, Head of the Financial and Administrative Control Bureau, Head of the General Personnel Bureau, Executive Advisor for the Coalition for Integrity and Transparency "Aman", Director General of Audit at the Ministry of Finance, Member of the Committee Central to Fatah, 50 public administration employees from the public institutions whose chiefs have been interviewed as partners in anti-corruption policy making.

\subsection{Statement of Purpose}

All countries in the world suffer from corruption but in different degrees. In Palestine corruption existed early since the establishment of the PNA due to the weakness of administration or the desire to gain illegal advantages. Other parties were forced to interfere to encounter corruption as policies of anti-corruption were issued. However, corruption continued to spread in some public institutions. The problem of the study could thus be shaped by the following question: to what extent the policy network had been able to contribute to the creation and implementation of policies against administrative corruption?

\subsection{Study Questions}

In addition to the main question, the researcher is seeking to answer the following questions:

1. What is the public policy network?

2. What is the expected role of policy network to reduce corruption?

3. What are the forms of corruption in public Palestinian organizations?

4. To what extent the spread of corruption in the Palestinian public sector institutions?

5. What is the extent of effect on corruption on Palestinian citizen?

\subsection{Study Objectives}

- Exploring the public policy network.

- Clarifying the expected role of policy network to reduce corruption.

- Investigating the forms of corruption in public Palestinian organizations.

- Clarifying the effect of corruption on the Palestinian public sector institutions?

- Clarifying the effect of corruption on Palestinian citizen?

\section{Methods and Techniques}

\subsection{Study Methodology}

The study adopted the descriptive analytical approach as well as historical approach.

\subsection{Study Procedures}

A number of interviews were held with participants in the drafting and implementation of public policies in the field of anti-corruption, focusing on the Anti-Corruption Authority, the Financial and Administrative Control Bureau, General Staff Bureau and the relevant community institutions.

\subsection{Data Sources}

1. Primary sources based on personal interviews.

2. Secondary sources based on literature, reports and previous studies.

\section{Data and Discussion}

\subsection{Public Policies}

A policy is the authoritive distribution of values on the society through the decisions and divided activities of those values according to the interaction between inputs, outputs and feedback (Eston, 1977, p. 94) .Further, public policies are the total of all formal and informal interactions between many involved parties in both local and central levels, those policies are the outcome of their well as they are members in public policies networks (Sharawi, n.d, p. 31) . Therefore, public policies are all what is issued by the government within the interaction of public networks with those orders, laws, regulations, projects, plans and strategies in order to achieve the goals and interests of the public.

\subsection{Corruption}

Corruption is one of the most dangerous challenges facing societies and countries; it has many dangerous effects on both democracy and sovereignty leading to breaches of human rights and the deterioration of life quality.

Although, there is no agreement in the literature on how to define the phenomenon of corruption, corruption as the misuse 
of public office for private gain (The Coalition for Accountability and Integrity, Corruptions: Reasons and results: Youth in Encounter, 2004). Specifically, government corruption is defined as the sale by government officials of government property for personal gain" (The Coalition for Accountability and Integrity, Tenth annual Report: status of anti-corruption in palestine, 2017). The Palestinian legislative council defined corruption as the breach of the laws and regulations issued accordingly; or the intended breach of public policies by the public servant (employee) in order to gain financial, social, administrative and other advantages from his post or position (Reviewing the opinions of citizens regarding anti-corruption in Palestine in 2013, 2014).

According to the previous definitions all countries in the world suffer from corruption; but it is wider and more dangerous in developing countries, especially in countries like Palestine with many social and political problems. As a need many polices were drawn to encounter corruption and reducing its, these polices started with the efforts of supporting nations and the laws issued by the government, and turned to be a network of public polices within different stages as we well mention later.

\subsection{The Most Relevance and Dangerous Forms of Corruption in Palestine}

Many forms corruption are practiced in Palestine; such as the case in other countries. The big corruption is the most spread form; other forms- according to Amman latest study are; (30.2\%), bribery 26.2\%, abuse of power 18\% (10.8\%), credit loss $(8.1 \%)$, and money laundering (6.7\%) (Reviewing the opinions of citizens regarding anti-corruption in Palestine in 2013, 2017) .

In a study by the Coalition for Integrity and Accountability conducted in 2013, $89 \%$ of the citizens asked for favoritism (Wastta), where $82 \%$ of the respondents believed that this is the most prevalent form of corruption, followed by moderation and favoritism in promotions and appointments in the public sector by $80 \%$, similar rates appeared in the survey of 2012, with $93.2 \%$ of respondents said that favoritism is the most prevalent forms of corruption in the public sector, A $89.7 \%$ of them resorted to the request of the medium to be able to obtain services from the public sector (Sharawi, n.d.) ${ }^{(1)}$. This type of corruption is no longer considered as black one and moved from grey scale to white scale. Amman's study of 2017 yielded same results, as $71 \%$ of the respondent agreed that it is the most spread from of corruption (Sharawi, n.d.).

\subsection{Effects of Corruption on Palestinian Public Sector and Palestinian Citizen}

In Palestine the negative effects of corruption affected the state and the citizens as well; as in all developing countries the corruption is widely spread in Palestine due to the weakness of political well and the absence of real well to carry out administrative reforms,

The effects extended from economic development to political development, all this lead to a problem in the social development too. Corruption costs Palestine a heavy cost in all levels, this varies between social problems and moral problems; as well as the real threaten to the ambitions of the Palestinian people in prosperity and development.

\subsection{Public Policies Network, Its Concept and Applications on the Polices of Anti-corruption in Palestine}

There are many parties to analyze the public polices network, in the past the state was the effective actor in such matter. The iron triangle of making and executing public policies come to the forth (State, legislators and stakeholders). With the change in the state role in such matter and the new role of organizations there were many trends to analyze the network of public policies (anti-corruption Commission in Palestine, Palestinian Universities sign an agreement with the commission to teach two courses about anti-corruption, 2017). The public policy network consists of all partners in public policy-making, such as public administration, parties, opposition, civil society institutions, research and advisory centers, lobby groups, parliament and the judiciary, as well as the government. The concept of the public policy network refers to the existence of policy-making groups that vary from one issue to another in the policy area and from time to time, thus having more than one communication pattern, different types of entanglements and various types of partnership that contribute to the formation of such policies (Meredith, Howard, \& Miller, 2001) .

Making these policies and their implementation under the microscope of control by these parties, to take these policies in a more serious and binding form.

\subsection{Components of Anti-corruption Public Polices Network in Palestine}

In the First Stage, before the first strategy of anti-corruption: In Palestine there was a classic policy network that does not exceed the iron triangle with its constituents (Public Administration, legislator, stakeholders) shows the role of other parties in the design and manufacture of anti-corruption policies, but the role of other parties In criticizing some of the

${ }^{10}$ Salwa, Sharawi, analyzing Public Policies in the $21^{\text {st }}$ Century, Cairo University, Political and Economic Science College, Pp51-55. 
writers of the phenomenon of corruption in the institutions of the Palestinian Authority, and criticizing the public of this phenomenon, and some institutions of civil society, in addition to the emergence of a role urged and urged by international institutions in support of the Palestinian Authority.

In the second phase, with the approval of anti-corruption law following the establishment of anti-corruption commission and the related persecution in 2010: between 2002 and 2010 the contributions were the same except for the graft law. However, this policy came into life in 2010 through the anticorruption law and all parties started to work seriously on encountering corruption all over the country.

The third phase is the launching of the first strategy of anti-corruption in Palestine 2012-2014. At this stage, the anti-corruption policy network has expanded to consist of the Anti-Corruption Authority, the government, parliament, party representatives, media, donors, some academics, The private sector, especially the banking sector, some civil society institutions led by Transparency International's current national security institution). The parties worked together to draw up the first anti-corruption strategy, but at the implementation stage a number of parties to the network did not participate but withdrew. Between the parties, and the people did not trust the efforts seriously.

The fourth phase is the launching of the second strategy to combat corruption 2015-2018: the implementation of the first strategy, the second strategy for combating corruption in the Palestinian public sector has been completed, and new members have entered the anti-corruption system as called by the Palestinian Anti-Corruption Authority, , The network was formed at this stage from a number of parties (the Anti-Corruption Commission, the Court and its Anti-Corruption Prosecution, the Government - its public administrations, lobby groups, interest groups, representatives of some parties and trade unions, And other media, some private sector institutions, especially banking, and Palestinian universities signed between 12 Palestinian universities and the Anti-Corruption Commission to be members of the system - and the introduction of anti-corruption course as an optional course for all disciplines, be mandatory for the specialization of law and public administration ).

However, despite the widespread network of anti-corruption policies, the efforts of the implementers vary in performance and the performers lack good coordination and complementarities of efforts. There is confusion in the understanding of each session, a clear lack of understanding among some, as well as confusion between policy makers and some institutions It has the task of reducing the spread of corruption, each sees himself the most effective actor.

The third strategy was then drawn from 2018-2022 to encounter corruption, which started from where its predecessor ended, and with the same mechanism, the implementation window now.

\subsection{Phases of Making Public Polices by Applying on Anti-Corruption Polices in Palestine}

Making policies process is the forming of the policy and applying this policy, the two sides of the press is a strong trend in public polices to turn initiatives into laws or regulations to applied effectively (Lars, 2012, p. 13) . This process contains many integrative processes, divided by Parson Lars into five phases, as follows (Saegh \& Shiqaqi, 1999); determining the problems of polices, forming policies suggestions, legalizing polices, applying public polices and evaluating those polices.

Researchers differ in their discussion of polices, however they agreed on several phases; those phases are:

The first phase: The initiative in putting public policies on the government Agenda: This phase means the existence of a problem that must be discussed and encountered by the government.

Anti-corruption problem on the Agenda of Palestinian government: the problem was identified through the general sense of the effect of this problem on people; therefore, many initiatives were set out to face the increasing problem of corruption. The initiatives were as follows:

Regulatory bodies: many reports indicated that there is corruption in Palestine, for example the report of 1997 indicated that senior officers in Palestine committed corruption (Kronz, et al.).

The Legislative Council formed a special committee to investigate the issue of corruption in the Palestinian National Authority (PNA) consisting of eight members (Palestinian Legislative Council. The Report provided to the Special Committee about the Report of Public Control director, the first annual Report of 1996, 1997) on 27/5/1997. This committee prepared its own rules and procedures, which were based on a set of general rules in terms of identifying suspected cases, and to request documents and address officials in the institutions of the Authority. The report of the Monitoring Committee in the Palestinian Legislative Council for 1998 has confirmed most of the conclusions contained in the report of the General Control Authority in 1997. The report, prepared by the committee, recommended that the Legislative Council should review the provisions of the law of the Public Control Authority, so that the oversight body becomes more effective and impartial by proposing the approval of the Legislative Council to appoint its chairman and obliging him to submit his annual report to the Council. State-owned enterprises, the involvement of the masses in the 
fight against corruption and many other recommendations, the government did not take practical steps (Mechanisms for Reforming Financial, Administrative and Economic Corruption in the PNA Institutions (Palestinian Citizen's Vision), 2007) (Abu-Rab \& Abu Khalaf, 1997).

International Bank Report: This report was issued in 1997 showing the need of encountering administrative corruption, the report submitted several suggestions for real reforms as well as identified the methods of motivating employees (Al-Masri, 2010).

The role of Palestinian Academics and Citizens: The role of citizens was very constructive in encountering corruption' as scholars dealt deeply with the problem and many studies were published in this concern (Al-Shuyab, n.d) (Indicators of corruption in the Arab world. Lebanon, The Arabic Organization of anti-corruption, 2010)

Initiatives of civil society organizations: The Coalition for Accountability and Integrity (AMAN) was established in the year 2000 upon an initiative by a number of Palestinian civil society organizations working in the fields of democracy, human rights, and good governance as a movement aims to combat corruption and enhance the values of integrity and principles of transparency and systems of accountability in the Palestinian society. Transparency International endorsed AMAN Coalition in 2006, where AMAN abides by the guiding principles of TI movement and with promoting its objectives and activities that adhere with the Palestinian context (Abu Dayeh, 2004) .

Pressure of international donors: international pressures increases on the PNA in order to start reforms and re-organizing its organizations, the US linked its donations to this trend (Shrawi, 1997) Hereby the problem reached the Agenda of the state and anti-corruption became a priority in Palestine.

The second phase: forming public polices: After the acceptance of the problem as a part of the political regime agenda, the regime must find the needed techniques to solve this problem; the forming of the policy contains the objectives as well as the plan and suggestion to achieve those objectives; as well as selecting the means of carrying out those plan and programs (Sharawi, n.d.).

There are many parties to analyze public polices, in the past the state was effective in this field however, now there are many trends and organization to analyze those policies, the main unit in the analysis is policy network (Sharawi, n.d.).

Forming polices of anti-corruption in Palestine: As a result of formal and informal interactions in both central and local to manage policy network (Qadeh, n.d), the PNA responded to all pressures and started with general polices to reduce corruption in the Palestinian public organizations.

In the middle of 2002, a new government was formed, which included many new faces. In addition, many reform steps were implemented, primarily the adoption of major laws such as the Basic Law of the Palestinian National Authority and the Judicial Authority Law of May 2002, (2002) (Nawfal, 2003) (Qadeh, n.d) ${ }^{(2)}$. However, this plan was frozen because of the political situation in the Palestinian territories, the siege of the Palestinian President, the Israeli invasion of all Palestinian cities, and the irregularity of the work in public institutions.

In 2004, for combating corruption in general and administrative corruption in particular, a decision was taken to establish the Palestinian Financial and Administrative Control Bureau pursuant to the provisions of Article (96) of the amended Palestinian Basic Law, and its work regulates its law no. (15) Of 2004. However, the powers of this body when detecting cases of corruption were terminated by issuing reports and forwarding them to the competent authorities (Palestinian anti-corruption Commission. Arabic anti-corruption commissions: Palestine as a model Paper Presented to Integrity and anti-corruption, 2012),

In 2005; illegal gains law number (1) of 2005 was issued. In 2010 the Palestinian president amended the law then issued anti-corruption law, this amendment is coping with the UN convention regarding anti-corruption; then the Palestinian anti-corruption commission (Abdelkareem, 2004.) started to act in the PNA territories as a means of carrying out this law. The law authorized the commission to (Palestinian anti-corruption Commission. Arabic anti-corruption commissions: Palestine as a model Paper Presented to Integrity and anti-corruption, 2012).

A deterring legislative and institutional environment that reduces opportunities of corruption.

Effective legislations, prosecution and judicial procedures to prosecute the corrupt and hold them accountable.

A social environment that supports and participates in anti-corruption efforts promotes the values of integrity, transparency and accountability and rejects any corruption-tolerant culture.

Develop bilateral and multilateral international cooperation, and relations with international organizations to enhance

2) Osama, Nawfal. Functional and Financial Evaluation of the Public Palestinian Budget, 2003, Palestinian Planning Center. Wael Qadeh. Political and Financial Reforms in PNA. www. Oppc, pna.net/mag/mag 13-14.html/ 
anti-corruption efforts.

The law of 2010 was a comprehensive, accurate and independent law in all means and efforts (Palestinian anti-corruption Commission. Arabic anti-corruption commissions: Palestine as a model Paper Presented to Integrity and anti-corruption, 2012) In order to fulfill the law a specialized persecution was established to deal with corruption cases; within special procedures and due to time to solve all cases (Palestinian anti-corruption Commission. Arabic anti-corruption commissions: Palestine as a model Paper Presented to Integrity and anti-corruption, 2012) .

In the year 2012; the national strategy of anti-corruption (2012-2014) was issued, the strategy relies first and foremost on the Palestinian Anti-Corruption Law No. 1, 2005 (amended). It takes into consideration the Palestinian institutional structures, with special attention to anti-corruption law institutions. The strategy regards the Palestinian Legislative Council (PLC) an integral implementing stakeholder in spite of its absence whilst implementing the previous strategy.

The implementation period of the previous strategy has witnessed Palestine's gaining international recognition as a non-member observer state at the United Nations (Palestinian anti-corruption Commission. Arabic anti-corruption commissions: Palestine as a model Paper Presented to Integrity and anti-corruption, 2012) Followed shortly by Palestine's accession to UNCAC, in addition to its accession to the Arab Convention for Combating Money Laundering and Terrorism Financing and the Arab Convention to Fight Corruption. This strategy derives its powers from these agreements in addition to the amended Anti-Corruption Law No. 1, 2005 (Al-Natsheh, 2018).

In 2015, another strategy was issued for the years 2015-2018; with the contribution of all effective organizations that participated in the previous strategy, and they contributed in issuing (2019-2022) strategy that started from the end of the previous one. This clarifies that the efforts of anti- corruption took a long time aiming to prevent and treat all corruption cases.

The third phase: Carrying out public policies: The phase of executing public policies is a meeting point between general management science and public policies analysis science, is whether the policies or programs were attractive and useful they will not be in use unless they are applicable from an administrative point of view (Sharawi, n.d.), the mission of carrying out those policies us the responsibility of general management in the first place; implementation is the link that keeps the means, methods and efforts directed towards the goals and purposes of public policies (Al-Kubaisi, 2008) .

Therefore, it is the peak of the government activities as it is a real translation for all practical efforts of carrying out different types of public policies (Yaqhi, 2010).

Carrying out policies of anti-corruption in Palestine: This started from the real faith of protecting public funds and respecting the laws according to the comprehensive and integrative views of all stakeholders (Abu Dayheh, 2013).After issuing the anti-corruption policies, effective organizations and institutions started to carry it out, each according to his specialization and authority. The national strategy of 2012- 2014 clarified those parties as follows (PNA, 2012)

1. The legislative Council (The unicameral legislature of the Palestinian Authority, elected by the Palestinian residents of the Palestinian territories of the West Bank and Gaza Strip. It currently comprises 132 members, elected from 16 electoral districts of the Palestinian Author, n.d)

2. The Executive Authority of the Palestinian Government: President, the Prime Minister and the Ministers of the Palestinian State.

3. Anti-Corruption Commission.

4. Public Prosecution.

5. Corruption Crimes Court.

6. Financial and Administrative Control Bureau

7. Civil society institutions.

8. Media.

9. Schools and Universities.

10. Internal control organizations.

11. Citizens.

Obstacles of Carrying out anti-corruption policies in Palestine: There are many obstacles hindering the real execution of the anti-corruption policies in Palestine, those are: technical, organizational, political, economic, media, ethical, social, cultural and environmental obstacles. 
Table 1. Obstacles that partners face

\begin{tabular}{|c|c|}
\hline Partner & Obstacles/Challenges \\
\hline $\begin{array}{l}\text { Anti-corruption Commission (PNA, } \\
\text { 2015) }\end{array}$ & $\begin{array}{l}\text { Continued occupation in the Palestinian territories, especially in } \\
\text { Jerusalem, and Israeli checkpoints } \\
\text { - The division between Gaza and the West Bank and the weak control } \\
\text { efforts in Gaza. } \\
\text { - Poor international coordination in the field of extradition and recovery of } \\
\text { criminal proceeds } \\
\text { - The general impression of the Palestinian homeland of the existence of } \\
\text { corruption and lack of confidence in the seriousness of fighting and hold } \\
\text { accountable the perpetrators. } \\
\text { - The weakness of the general culture in terms of the concept of corruption } \\
\text { and its dangers and weak general readiness to report corruption } \\
\text { - Poor involvement of the private sector and cooperatives in efforts to } \\
\text { implement the anti-corruption strategy }\end{array}$ \\
\hline $\begin{array}{l}\text { The Palestinian Center for the } \\
\text { Independence (Musawa) (Musawa } \\
\text { Center, 2013) }\end{array}$ & $\begin{array}{l}\text { The need to reconsider the anti-corruption law and amending it. } \\
\text { The weak public awareness about the importance of reporting corruption. } \\
\text { The need to spread a culture that anti-corruption efforts are for protection } \\
\text { not revenge. }\end{array}$ \\
\hline $\begin{array}{l}\text { The legislative council (Al-khatib, } \\
\text { 2018) }\end{array}$ & Not fulfilling its tasks and this is a dangerous obstacle \\
\hline $\begin{array}{l}\text { The Coalition for Accountability and } \\
\text { Integrity (AMAN) (Al-Shuaibi, 2018) }\end{array}$ & $\begin{array}{l}\text { The national strategy of anti-corruption is a plan not a strategy. } \\
\text { There is no coordination between Amman and other organizations. }\end{array}$ \\
\hline Some effective parties & $\begin{array}{l}\text { The work of the Legislative Council has ceased. } \\
\text {-Sinking of the administrative apparatus } \\
\text {-Shortening the media in its various forms } \\
\text {-Weak coordination between the network of actors. } \\
\text {-Ambiguity of objectives in anti-corruption policies. } \\
\text { Weak policies, laws, regulations, strategies and plans for control. }\end{array}$ \\
\hline The citizen & $\begin{array}{l}\text { ews about the useless efforts of anti-corruption and the weak courts dealing } \\
\text { with corruption }\end{array}$ \\
\hline
\end{tabular}


Table 2. Obstacles to public policy-making from the point of view of some public administration employees

\begin{tabular}{|c|c|c|c|c|c|c|c|c|c|c|}
\hline \multirow{2}{*}{$\begin{array}{l}\begin{array}{l}\text { Num- } \\
\text { ber }\end{array} \\
14\end{array}$} & Paragraphs & \multicolumn{5}{|c|}{ Percentage of answers } & \multirow[t]{2}{*}{ Average } & \multirow{2}{*}{$\begin{array}{l}\text { Standard } \\
\text { Deviation }\end{array}$} & \multirow{2}{*}{$\begin{array}{l}\text { Percen } \\
\text {-tage }\end{array}$} & \multirow{2}{*}{$\begin{array}{l}\text { Estima-ti } \\
\text { on }\end{array}$} \\
\hline & $\begin{array}{l}\text { Stopping the work of } \\
\text { the Legislative Council }\end{array}$ & $\begin{array}{l}\text { Very } \\
\text { high }\end{array}$ & high & middle & low & $\begin{array}{l}\text { Very } \\
\text { low }\end{array}$ & & & & \\
\hline 13 & $\begin{array}{l}\text { Partisan, factional, and } \\
\text { tribal considerations. }\end{array}$ & 40.6 & 45.3 & 6.3 & 5.5 & 2.3 & 4-16 & 0.94 & 83.28 & $\begin{array}{l}\text { Very } \\
\text { high }\end{array}$ \\
\hline 3 & $\begin{array}{l}\text { Sagging of the } \\
\text { administrative system } \\
\text { in the Palestinian } \\
\text { public sector }\end{array}$ & 24.2 & 54.7 & 16.4 & 3.1 & 1.6 & 3.97 & 0.82 & 79.38 & High \\
\hline 11 & $\begin{array}{l}\text { Poor coordination } \\
\text { between the network of } \\
\text { actors }\end{array}$ & 20.3 & 56.3 & 19.5 & 3.1 & 0.8 & 3.92 & 0.77 & 78.44 & High \\
\hline 1 & $\begin{array}{ll}\text { Weakness of policies } \\
\text { "laws, } & \text { regulations, } \\
\text { strategies, and plans". }\end{array}$ & 18.8 & 57 & 17.2 & 6.3 & 0.8 & 3.87 & 0.82 & 77.34 & High \\
\hline 12 & $\begin{array}{l}\text { Weakness of political } \\
\text { will. }\end{array}$ & 20.3 & 51.6 & 19.5 & 7.8 & 0.8 & 3.83 & 0.87 & 76.56 & High \\
\hline 10 & $\begin{array}{l}\text { Failure to specify the } \\
\text { time and spatial } \\
\text { framework for "control } \\
\text { programs and projects". }\end{array}$ & 22.7 & 50 & 18.8 & 3.9 & 4.7 & 3.82 & 0.98 & 76.41 & High \\
\hline 16 & $\begin{array}{l}\text { Conflicts of interests } \\
\text { between those who } \\
\text { implement } \\
\text { anti-corruption } \\
\text { policies. }\end{array}$ & 18.8 & 50.8 & 23.4 & 6.3 & 0.8 & 3.80 & 0.84 & 76.09 & High \\
\hline 17 & $\begin{array}{l}\text { Ignoring } r \text { some } \\
\text { corruption cases for } \\
\text { fear of interrupting } \\
\text { foreign aid. }\end{array}$ & 21.9 & 45.3 & 25 & 7 & 0.8 & 3.80 & 0.89 & 76.09 & High \\
\hline 4 & $\begin{array}{l}\text { Ambiguity of } \\
\text { anti-corruption policies } \\
\text { objectives }\end{array}$ & 16.4 & 53.9 & 21.1 & 7.8 & 0.8 & 3.77 & 0.84 & 75.47 & High \\
\hline 2 & $\begin{array}{l}\text { overlapping between } \\
\text { anti-corruption } \\
\text { policies. }\end{array}$ & 14.1 & 53.1 & 25 & 7 & 0.8 & 3.73 & 0.82 & 74.53 & High \\
\hline 9 & $\begin{array}{l}\text { Insufficient role of the } \\
\text { media }\end{array}$ & 9.4 & 57.8 & 26.6 & 5.5 & 0.8 & 3.70 & 0.75 & 73.91 & High \\
\hline 15 & $\begin{array}{l}\text { Anti-corruption } \\
\text { policies and } \\
\text { mechanisms do not } \\
\text { comply with local } \\
\text { legislation and penal } \\
\text { laws. }\end{array}$ & 15.6 & 48.4 & 20.3 & 13.3 & 2.3 & 3.62 & 0.98 & 72.34 & High \\
\hline 7 & $\begin{array}{l}\text { Weak availability of a } \\
\text { modern financial and } \\
\text { administrative database } \\
\text { for monitoring and } \\
\text { evaluation. }\end{array}$ & 12.5 & 40.6 & 30.5 & 14.1 & 2.3 & 3.47 & 0.96 & 69.38 & High \\
\hline 6 & $\begin{array}{l}\text { The limited } \\
\text { technological } \\
\text { capabilities available } \\
\text { for the purpose of } \\
\text { implementing } \\
\text { anti-corruption policies }\end{array}$ & 7 & 49.2 & 26.6 & 15.6 & 1.6 & 3.45 & 0.89 & 68.91 & High \\
\hline 5 & $\begin{array}{l}\text { Weakness of financial } \\
\text { means designed to } \\
\text { achieve the objectives } \\
\text { of anti-corruption } \\
\text { policies. }\end{array}$ & 13.3 & 37.5 & 27.3 & 19.5 & 2.3 & 3.40 & 1.02 & 67.97 & High \\
\hline 8 & $\begin{array}{l}\text { Weakness of human } \\
\text { resources }\end{array}$ & 10.2 & 41.4 & 20.3 & 25.8 & 2.3 & 3.31 & 1.04 & 66.25 & High \\
\hline & Average & & & & & & 3.70 & 0.47 & 74.10 & - \\
\hline
\end{tabular}


It is clear that there are many obstacles facing the execution of public policies, and this explains the weakness in applying those policies in general. It is worth to mention that the weak political well is the most important obstacle and there is a need to overcome this obstacle for the effective execution of anti-corruption public policies.

The fourth phase: Evaluating public policies by applying on Palestinian anti-corruption policies

In order to enable the policies from achieving the desired goals, evaluation must be associated with the execution efforts' this to ensure the effective application of those policies and to update them if needed (Al-Fehdaw, 2001)

Evaluation id a continuous process containing the analysis of data and information for any program or project (Anderson \& Al-kubaisi, 1998), and it effects the success of the whole process.

In Palestine systems, approach method is used, by studying income operations and outcomes. During the evaluation of the first strategy many gaps were found and modified then included in other strategies; the most important need now is to maintain coordination and updating all public policies in the future to ensure the effective application of all policies (Shrawi, 2004)

However, this approach is classic, taking into consideration quantity not quality and neglecting the real obstacles that hindering the application of those strategies.

\section{Results}

The policies network has an effective role in anti-corruption efforts in all phases on making those policies starting from the first phase till the final one (evaluation).

Anti-corruption policies and their implementation, especially the Anti-Corruption Commission, were able to impose themselves on the Palestinian scene, despite the weakening of the citizen's confidence in the seriousness of the anti-corruption intentions, but what he planned was implemented smoothly and in peace.

3. There is a conflict of interests between partners, which resulted in the withdrawal of some parties from the network, as Hamas and the Coalition for Integrity and Transparency "Aman", have done. considering anti-corruption strategies as tactical plans.

4. Nevertheless, the anti-corruption policy implementation network faces obstacles in all stages of policymaking, which represented by the existence of occupation, division, weak citizens' trust in the seriousness of implementation, suspending the work of the Legislative Council for nearly a decade, political and security and economic volatility.

5. Weakness in the integration of efforts and coordination between the implementing partners, and thus a deficient performance on the ground.

6. Weakness in separating the three legislative, judicial and executive authorities, which led to a conflict of opinions and interests during implementation.

7. Weakness in media's role from the start of the anti-corruption policy-making process until the end of implementation process.

\section{Recommendations}

1. The real separation of the three authorities, and prevent overlapping between their interests.

2. Holding legislative elections so that its members can represent the partnership of the Palestinian citizen in an effective democratic manner.

3. Activate the formal and informal media for effective partnership in making and implementing anti-corruption policies, then the work of transparent media with declared results to citizens.

4. Activating the role of the Palestinian citizen in making anti-corruption policies, especially in the implementation phase, in addition to making him aware of the importance of his participation in this process.

5. Ending the internal Palestinian conflict between the political parties, which weakened the full representation of the Palestinian people in sitting policies for anti-corruption.

6. Finding effective mechanisms to monitor and evaluate anti-corruption policies.

7. Seek to integrate and coordinate the efforts of all members of the Anti-Corruption Policy Network and overweigh the public interest over the private one.

\section{References}

The Coalition for Accountability and Integrity, Tenth annual Report: status of anti-corruption in palestine. (2017).

Abdelkareem, N. (2004). The role of International Funding in Empowering and Developing the Palestinian Communit. 
Human Development Report.

Abu, D. A. (2004). The Reform Process in PNA Organizations. Ramallah: The Palestinian Center of Political and Survey Studies.

Abu, D. A. (2013). Corruption: Medicine \& Food. AMAAN: AMAAN Publication.

Abu-Rab, M., Ahmed, H., \& Abu, K. N. (1997). The state in a changing World. The international Bank for Building and construction.

Al-Fehdaw, F. (2001). Public Policy from an comprehensive Approach. Amman: Al-Masyrah Publishers.

Al-khatib, J. (2018, 5 2). The Deputy of the Legislative Council Directo. (P. Interview, Interviewer)

Al-Kubaisi, A. (2008). Public Policies: An approach to develop University Performance (1st ed.). Cairo: Arabic Organization of Administrative development.

Al-Masri, A. (2010). Corruption in the Palestinian Authority and the effect of fighting it in enhancing loyalty of Palestinians (1994- 2006). Unpublished Master thesis. Nablus: Al-Najah University.

Al-Natsheh, R. (2018). Manager of Palestinian anti-corruption Commission. Personal Interview.

Al-nitseh, R., \& Amarneh, R. (2018). Interview .

Al-Shuaibi, A. (2018). Adviosr of AMAAN Council. (P. Interview, Interviewer)

Al-Shuyab, A. (n.d). Studying the Palestinian Experiment. In Ahmed Saleem eta.

Anderson, J., \& Al-kubaisi, A. (1998). Making Public Policies. Amman: Al-Masyrah Publishers.

Eston, D. (1977). The Analysis of political system. (M. a. Bown, Ed.) Georgetown: the Dorsey Press Homewoo.

Indicators of corruption in the Arab world. (2010). Lebanon, The Arabic Organization of anti-corruption (1st ed.). Arabic Unity Studies Cente.

Kronz, S., Abu, S. Y., Shuybi, A., Yazeed, K., Shrafi, K., Abdelqaqder, H., ... Khrisheh, H. (1997). The legislative Councithe Report about Public Control director According to the 1997 Report. Ramallah: legislative Council.

Lars, P. (2012). Politics and the Policymaking Process. Texas: National Press Inc.

Mechanisms for Reforming Financial, Administrative and Economic Corruption in the PNA Institutions (Palestinian Citizen's Vision). (2007). Al-Quds Open University for Research and Studies, 3(10).

Meredith, E., Howard, C., \& Miller, R. (2001). Social policy, public policy: from problems to practice. South Wales, Australia: Allen \& Unwin.

Musawa Center. (2013). Seminar on the Obstacles of anti-corruption efforts. Palestine.

Nawfal, O. (2003). Functional and Financial Evaluation of the Public Palestinian Budget.

Palestinian anti-corruption Commission. Arabic anti-corruption commissions: Palestine as a model Paper Presented to Integrity and anti-corruption. (2012). Nayef Arabic University of Security sciences.

Palestinian Legislative Council. (1997). The Report provided to the Special Committee about the Report of Public Control director, the first annual Report of 1996. Ramallah: Palestinian Legislative Council.

PNA. (2012). National Strategy of anti-corruption 2012-214. Palestine. Ramallah.

PNA. (2015). The National Strategy of anti-corruption of 2015-3018.

Qadeh, W. (2019). Political and Financial Reforms in PNA. Retrieved from http:// www.oppc. pna.net/mag/mag9-10

Reviewing the opinions of citizens regarding anti-corruption in Palestine in 2013. AMMAN-RAMALLAH: The Coalition for Accountability and Integrity.

Saegh, Y., \& Shiqaqi, K. (1999). Strengthen PNA Institutions. Report of the working team under foreing relationships American Committee.

Sharawi, S. Analyzing Public Policies in the 21th Century. Cairo: Cairo University, Political and Economic College.

Shrawi, S. (1997). Making Environment Policies in Egypt. Cairo: American University, social Studies Center.

Shrawi, S. (2004). Program of Evaluating and following up performence from gender perspective (1st ed.). Cairo: National Council for Women in collaboration with (UNIFEM), the United Nations Population Fund (UNFPA) and theand the Center for Public Administration Studies and Consultations, Faculty of Economics and Political Science, Cairo University. 
Simcha, W. (1983). New Direction in the study of administrative corruption. Public Administratoin Review, (43), 211. https://doi.org/10.2307/975428

The Coalition for Accountability and Integrity, Corruptions: Reasons and results: Youth in Encounter (Vol. 1). (2004). Anti-Corruption Publications.

Yaqhi, A. (2010). Public Policies: Theory and Practice. Arabic Organization of Administrative development, 159.

\section{Copyrights}

Copyright for this article is retained by the author(s), with first publication rights granted to the journal.

This is an open-access article distributed under the terms and conditions of the Creative Commons Attribution license (http://creativecommons.org/licenses/by/4.0/). 